\title{
Karakterisasi Conducted Emission Noise pada Inverter di Sistem Photovoltaic Off-Grid
}

\section{(Characterization of Conducted Emission Noise on Inverter in Off-Grid Photovoltaic System)}

\author{
Yudhistira $^{1}$, Dwi Mandaris ${ }^{2}$, Yoppy ${ }^{3}$, Hutomo Wahyu Nugroho ${ }^{4}$, Prayoga Bakti ${ }^{5}$, Bayu Utomo ${ }^{6}$, Tyas Ari Wahyu ${ }^{7}$, \\ Siddiq Wahyu Hidayat ${ }^{8}$, Ferdaus Ario Nurman ${ }^{9}$, Tri Desmana Rachmilda ${ }^{10}$, Deny Hamdani ${ }^{11}$
}

\begin{abstract}
The conducted emission noise caused by the inverter in the off-grid photovoltaic (PV) system has been characterized. Noise that propagates in the conduction path was generated from the phenomenon of inverter switching for the power conversion process from direct current (DC) to alternating current (AC). The IEC 62920: 2017 and CISPR 25: 2016 standards were used to measure the noise generated by the inverter on the DC side. The conducted emission noise measurements for the inverter were carried out in three conditions, namely no-load condition, connected to a $60 \mathrm{~W}$ incandescent lamp load, and connected to the incandescent lamp load and dimmer for power variation. Measurements were made on five inverters with different power capacities and output types. The $200 \mathrm{~W}, 300 \mathrm{~W}$, and $700 \mathrm{~W}$ outputs were for the modified sine wave output voltage, while the $500 \mathrm{~W}$ and $1,000 \mathrm{~W}$ were for pure sine wave output voltage. The measurement results show that when the inverter is connected to the load of the incandescent lamp and the dimmer, the $500 \mathrm{~W}$ and $1,000 \mathrm{~W}$ pure sine wave inverters have a low peak noise level and less potential to cause electromagnetic interference on the $\mathrm{DC}$ side.
\end{abstract}

Intisari-Gangguan elektromagnetik berupa conducted emission noise yang ditimbulkan oleh inverter pada sistem photovoltaic (PV) off-grid telah berhasil dikarakterisasi. Noise yang merambat pada jalur konduksi dihasilkan dari fenomena switching inverter untuk proses konversi daya dari listrik searah (DC) menjadi arus bolak balik (AC). Standar IEC 62920:2017 dan CISPR 25:2016 digunakan untuk mengukur noise yang dihasilkan oleh inverter di sisi DC. Pengukuran conducted emission noise pada inverter dilakukan dalam tiga kondisi, yakni kondisi tanpa beban, terhubung dengan beban lampu pijar $60 \mathrm{~W}$, dan terhubung dengan beban lampu pijar beserta dimmer untuk variasi daya. Pengukuran dilakukan pada lima buah inverter dengan kapasitas daya dan jenis keluaran (output) yang berbedabeda, yaitu $200 \mathrm{~W}, 300 \mathrm{~W}$, dan $700 \mathrm{~W}$ untuk tegangan keluaran modified sine wave serta $500 \mathrm{~W}$ dan $1.000 \mathrm{~W}$ untuk tegangan keluaran pure sine wave. Hasil pengukuran menunjukkan bahwa pada kondisi inverter terhubung dengan beban lampu pijar beserta dimmer, inverter model pure sine wave $500 \mathrm{~W}$ dan $1.000 \mathrm{~W}$

1-8 Pusat Penelitian Teknologi Pengujian - LIPI, Gd. 417, Kawasan PUSPIPTEK, Tangerang Selatan. 15314. INDONESIA (tlp:021-7560227, 021-75871137; fax:021-7560227; e-mail: yudh002@lipi.go.id)

${ }^{9}$ PT. LEN Industri (Persero), Jl. Soekarno Hatta 442, Bandung. 40254, INDONESIA (tlp: +62-22-5202682; e-mail: ferdaus.ario@len.co.id)

10,11 Sekolah Teknik Elektro dan Informatika - ITB, Jl. Ganesha No. 10, Bandung. 40132. INDONESIA (tlp:022-2502260; e-mail: deny.hamdani@gmail.com) memiliki peak noise level yang cukup rendah dan berpotensi lebih sedikit untuk menimbulkan gangguan elektromagnetik di sisi DC.

Kata Kunci-Inverter, Conducted Emission Noise, DC-LISN, Photovoltaic Off-Grid.

\section{PEndahuluan}

Seiring dengan meningkatnya kebutuhan listrik rumah tangga, Energi Baru Terbarukan (EBT) menjadi solusi yang cukup diminati. Penggunaan photovoltaic (PV) sebagai bagian dari EBT mampu memaksimalkan penggunaan energi matahari untuk menghasilkan listrik, terutama untuk daerah-daerah pesisir dan pedalaman yang kurang mendapatkan akses listrik. Beberapa tahun terakhir, pemerintah tengah gencar melakukan gerakan untuk pemasangan sistem PV di atap perumahan supaya penetrasi EBT meningkat hingga 23\% di tahun 2025 [1]. Sistem PV tersebut ada yang sifatnya hanya terhubung ke beban listrik (off-grid), terhubung langsung ke jaringan PLN (grid-tied), maupun yang dapat bergabung (hybrid) dengan sumber EBT lainnya, seperti pembangkit listrik tenaga angin [2]. Pada makalah ini, tinjauan sistem PV dititikberatkan pada sistem PV off-grid guna memperoleh hasil yang komprehensif terhadap kondisi lingkungan yang kesulitan mendapat akses listrik dari PLN.

Secara umum, pada sistem PV off-grid terdapat beberapa komponen elektronik yang berfungsi untuk mendukung proses konversi energi dan konversi daya, yakni panel PV dan inverter. Panel PV dapat mengubah energi cahaya menjadi energi listrik dengan sifat aliran arus searah (DC), sedangkan inverter merupakan peralatan elektronik yang digunakan untuk mengonversi tegangan dan arus yang dihasilkan oleh panel PV sehingga dapat digunakan oleh beban peralatan listrik, yakni beban listrik arus bolak-balik (AC).

Dengan hadirnya peralatan elektronik tersebut, timbulnya gangguan elektromagnetik atau electromagnetic interference (EMI) tidak dapat dihindari, terutama pada inverter yang bertugas untuk melakukan switching saat mengonversi daya listrik dari DC ke AC [3]-[5]. Proses konversi daya listrik inilah yang dapat menghasilkan sinyal-sinyal yang tidak diinginkan dan berfrekuensi tinggi, baik secara konduksi maupun radiasi, karena adanya aktivitas penyakelaran cepat (fast switching). Proses fast switching berpotensi menghasilkan arus noise yang merambat di jalur DC sehingga dapat memengaruhi umur pakai pada perangkat yang ada di sisi DC dan dapat pula mengganggu frekuensi radio [6]. 
Selain itu, proses switching yang terjadi pada inverter biasanya menggunakan komponen-komponen seperti transistor Metal Oxide Silicon Field Effect Transistor (MOSFET) sebagai saklar, crystal oscillator sebagai pengontrol buka tutup saklar (frekuensi), dan transformator sebagai penguat tegangan. Faktor induktans dan kapasitans parasitik pada frekuensi tinggi menjadi pelengkap timbulnya gangguan elektromagnetik berupa noise pada inverter sehingga noise tersebut dapat terkopel pada jalur masukan (input) dan keluaran (output) PV inverter secara konduksi [7]-[10].

Terkait gangguan elektromagnetik yang terjadi pada jalur konduksi akibat penggunaan inverter, beberapa penelitian telah berhasil mendeskripsikan adanya perambatan gangguan emisi konduksi (conducted emission noise) yang terjadi di sisi sumber dan panel PV akibat adanya variasi impedans pada sisi AC inverter yang terhubung langsung ke jaringan (on-grid) [11]. Ada pula penelitian yang memberikan analisis conducted emission akibat adanya common mode noise dan differential mode noise pada penggunaan Switch Mode Power Supply (SMPS) secara simulasi maupun eksperimen yang berdampak langsung pada conducted emission noise [12], [13]. Dilaporkan pula bahwa kenaikan noise dari conducted emission sangat mungkin dipengaruhi oleh kondisi pentanahan, yakni single point, multipoints, dan hybrid grounding pada sistem PV [14]. Namun, penelitian yang berfokus pada gangguan konduksi yang timbul akibat penggunaan inverter pada sistem PV offgrid belum banyak dilakukan karena sebagian besar fokus penelitian tentang sistem PV lebih kepada topik yang berkaitan dengan efisiensi konversi energi. Padahal, gangguan yang ditimbulkan pada sisi DC inverter tidak kalah penting untuk dianalisis karena dapat memengaruhi kondisi lingkungan elektromagnetik di sekitarnya.

Cukup banyaknya potensi gangguan elektromagnetik yang berasal dari inverter menunjukkan perlunya dilakukan karakterisasi conducted emission noise inverter pada sistem PV off-grid, baik dalam kondisi tanpa beban maupun saat diberi beban pada sisi AC inverter. Dengan demikian, karakteristik noise yang timbul dapat diamati perubahannya terhadap ada atau tidaknya beban di sisi AC inverter. Pada akhirnya, hasil pada makalah ini diharapkan dapat memberikan gambaran tinggi atau tidaknya noise level yang dihasilkan oleh beberapa inverter yang dijual bebas di pasaran.

Kebaruan yang ada pada makalah ini terletak pada karakterisasi conducted emission noise inverter di jalur DC, baik dalam kondisi standalone maupun dalam kondisi terhubung dengan beban di sisi AC. Sampel inverter yang hendak diukur dipilih berdasarkan kapasitas daya yang biasa digunakan pada sistem PV off-grid, yakni dalam rentang 200 $\mathrm{W}$ hingga $1.000 \mathrm{~W}$ [15], [16]. Selain itu, teknik pengukuran yang digunakan mengacu pada standar IEC 62920:2017 dan CISPR 25:2016. Standar IEC 62920:2017 digunakan terkait set-up pengukuran dan batasan emisi conducted emission noise dari inverter, sedangkan kriteria alat ukur bantu yang berfungsi untuk memperoleh karakteristik noise tersebut terdapat pada standar CISPR 25:2016, yakni DC Line Impedance Stabilization Network (DC-LISN) [17], [18]. Adapun standar CISPR 25:2016 digunakan sebagai acuan penggunaan DC-

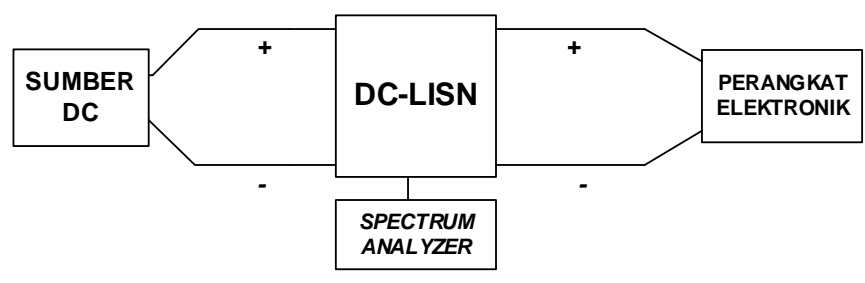

Gbr. 1 Skema pengukuran conducted emission noise pada perangkat elektronik.

LISN sebagai penangkap noise konduksi yang berasal dari inverter yang selanjutnya dibaca oleh alat ukur.

Makalah ini terdiri atas beberapa bagian. Bagian II menjabarkan teori singkat mengenai conducted emission noise dan DC-LISN sebagai alat bantu untuk mengukur noise level dari inverter. Di bagian III terdapat alur kerja dari penelitian dan set-up pengukuran berdasarkan standar serta alat ukur dan komponen elektronik yang digunakan. Selanjutnya, di bagian IV, seluruh hasil pengukuran dari berbagai kondisi ditampilkan dan dibahas secara menyeluruh. Pada akhirnya, kesimpulan dari hasil penelitian disampaikan pada bagian $\mathrm{V}$.

\section{CONDUCTED EMISSION NOISE}

Secara umum, gangguan elektromagnetik yang ditimbulkan oleh perangkat elektronik melalui penghantar (konduktor) dapat diinterpretasikan sebagai arus noise yang merambat pada jalur konduksi sehingga sangat berpotensi mengganggu peralatan elektronik lainnya melalui sumber tegangan. Hal ini disebut juga sebagai emisi gangguan elektromagnetik di jalur konduksi atau conducted emission noise.

Beberapa teknik untuk mengidentifikasi noise pada kasus conducted emission telah banyak dilakukan, salah satunya adalah dengan menggunakan alat bantu pengukuran berupa Line Impedance Stabilization Network (LISN) yang dapat berfungsi sebagai penyedia impedans yang stabil dan pemisah noise yang berasal dari sumber gangguan agar tidak diteruskan ke sumber tegangan. Selanjutnya, noise yang ditangkap oleh LISN akan diteruskan ke alat ukur, yakni spectrum analyzer, guna mendapat gambaran terkait tinggi atau tidaknya noise level yang ditimbulkan oleh sumber gangguan [19], [20]. Skema diagram untuk sistem pengukuran conducted emission noise pada jalur DC secara umum ditampilkan pada Gbr. 1 [21], [22].

Pada gambar tersebut, pengukuran noise pada perangkat elektronik (beban) yang terhubung dengan sumber tegangan AC dilakukan oleh DC-LISN dan spectrum analyzer. Adapun rentang frekuensi pengukuran conducted emission noise, mengacu pada standar IEC 62920:2017, adalah $150 \mathrm{kHz}$ sampai $30 \mathrm{MHz}$, yakni masuk dalam kategori frekuensi tinggi. Dengan adanya DC-LISN, impedans di kedua sisi tetap stabil $(50 \Omega)$ sehingga perangkat elektronik tetap dapat beroperasi dengan normal.

Fungsi lain dari DC-LISN adalah sebagai media peredam noise dari sumber tegangan sehingga hasil pengukuran noise oleh alat ukur hanya noise yang berasal dari inverter. Oleh karena itu, sumber tegangan harus dibuat sedemikian rupa sehingga tidak menimbulkan noise tambahan yang dapat mengganggu hasil pengukuran. Untuk skala laboratorium, 


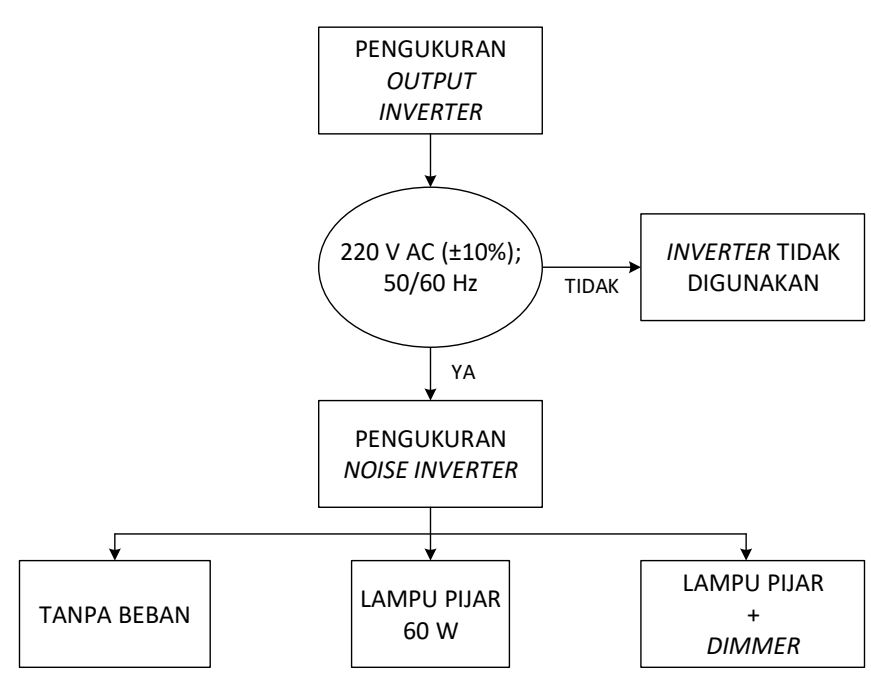

Gbr. 2 Diagram alir pengukuran conducted emission noise inverter PV.

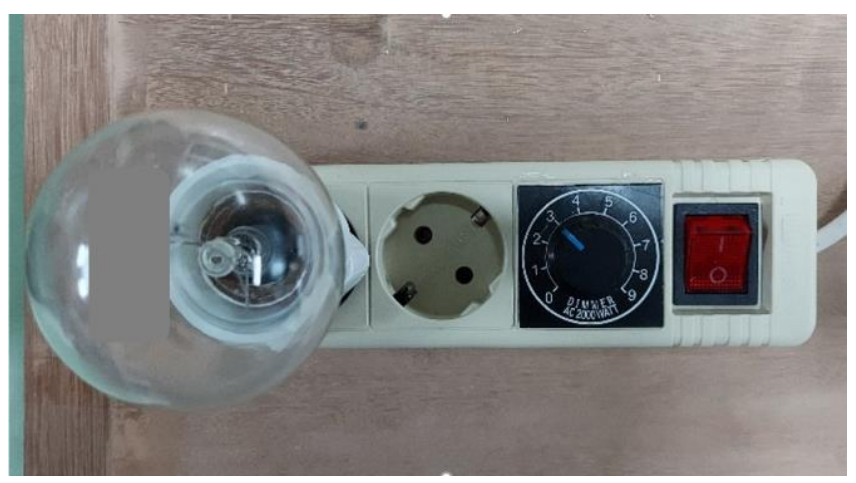

Gbr. 3 Lampu pijar $60 \mathrm{~W}$ beserta dimmer.

sumber tegangan DC dapat berupa baterai yang berperan sebagai pengganti sumber DC dari panel PV [18].

\section{PenguKuran CONDUCTED EMISSION NOISE INVERTER}

Alur kerja pengukuran conducted emission noise ditampilkan pada Gbr. 2. Beberapa inverter yang dipersiapkan untuk dilakukan pengukuran conducted emission noise adalah inverter $200 \mathrm{~W}, 300 \mathrm{~W}, 500 \mathrm{~W}, 700 \mathrm{~W}$, dan $1.000 \mathrm{~W}$. Spesifikasi ini dipilih karena mempertimbangkan penggunaan daya rata-rata sehari-hari di masyarakat perumahan serta mengikuti mayoritas klasifikasi listrik perumahan pada saat ini, yakni $450 \mathrm{~W}$ dan $900 \mathrm{~W}$ [23], [24]. Inverter yang digunakan memiliki spesifikasi keluaran gelombang yang berbeda, yakni pure sine wave dan modified sine wave. Inverter model pure sine wave memiliki tegangan keluaran yang lebih sinusoidal dibandingkan dengan model modified sine wave sehingga mendekati bentuk tegangan keluaran dari PLN. Namun, dari segi harga, inverter model modified sine wave lebih terjangkau sehingga banyak pula digunakan untuk penerangan maupun pengisian daya baterai gawai. Dengan mempertimbangkan beban yang terhubung ke inverter, spesifikasi keluaran inverter diharapkan menghasilkan keluaran tegangan RMS $220 \mathrm{~V}$ $( \pm 10 \%)$ dan frekuensi $50 / 60 \mathrm{~Hz}$.

Selanjutnya, pengukuran conducted emission noise dilakukan dalam tiga kondisi, yakni dalam kondisi tanpa beban, kondisi pembebanan lampu pijar $60 \mathrm{~W}$, dan kondisi variasi

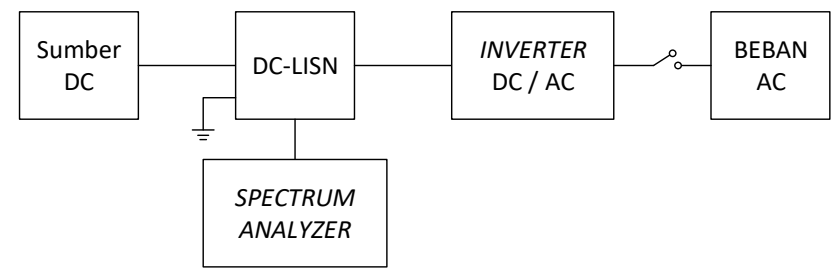

Gbr. 4 Set-up pengukuran conducted emission noise inverter PV.

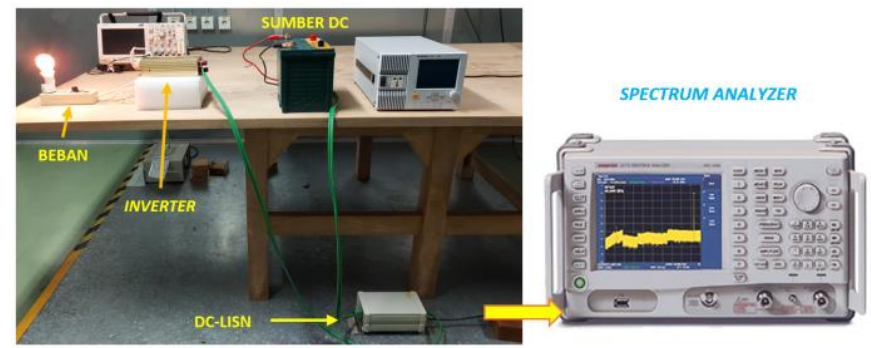

Gbr. 5 Perancangan sistem pengukuran conducted emission noise inverter PV.

daya lampu pijar menggunakan dimmer guna memperoleh karakteristik conducted emission noise bila dilakukan variasi daya lampu. Lampu pijar $60 \mathrm{~W}$ dipilih dengan mempertimbangkan daya rata-rata yang biasa digunakan untuk penerangan di kawasan pemukiman, sedangkan dimmer berfungsi sebagai pengendali besarnya daya yang diteruskan ke lampu pijar. Gbr. 3 menampilkan set-up lampu beserta dimmer. Adapun set-up dan perancangan sistem pengukuran conducted emission noise berdasarkan standar IEC 62920:2017 dan CISPR 25:2016 ditampilkan pada Gbr. 4 dan Gbr. 5 [17], [18].

Sumber DC yang digunakan sebagai pemasok daya untuk inverter adalah baterai $12 \mathrm{~V}$. Pada saat inverter bekerja, baik tanpa beban maupun diberi beban di sisi AC, noise pada jalur konduksi diukur melalui DC-LISN dan diteruskan ke spectrum analyzer untuk dilakukan pengolahan data peak noise level. Data yang ditampilkan adalah spektrum frekuensi dari $150 \mathrm{kHz}$ sampai $30 \mathrm{MHz}$ dengan conducted emission peak noise level dalam satuan $\mathrm{dB} \mu \mathrm{V}$.

\section{HASIL DAN PEMBAHASAN}

Hasil pengukuran tegangan keluaran pada masing-masing inverter, yakni $200 \mathrm{~W}, 300 \mathrm{~W}, 500 \mathrm{~W}, 700 \mathrm{~W}$, dan $1.000 \mathrm{~W}$, diperlihatkan pada Gbr. 6. Tegangan keluaran dan frekuensi yang terukur dari masing-masing inverter menunjukkan nilai yang masih memenuhi kriteria, yakni tegangan RMS $220 \mathrm{~V}$ $( \pm 10 \%)$ dan frekuensi $50 / 60 \mathrm{~Hz}$. Tampak jelas pula perbedaan profil gelombang tegangan yang dihasilkan oleh inverter pure sine wave $(500 \mathrm{~W}$ dan $1.000 \mathrm{~W})$ dan modified sine wave $(200$ $\mathrm{W}, 300 \mathrm{~W}$, dan $700 \mathrm{~W}$ ).

Berdasarkan hasil yang diperoleh dari bentuk tegangan keluaran masing-masing inverter, hasil pengukuran conducted emission noise pada jalur DC inverter dibagi menjadi dua bagian, yaitu inverter model pure sine wave dan modified sine wave dengan tiga kondisi pengukuran, yakni kondisi tanpa beban, kondisi beban lampu pijar $60 \mathrm{~W}$, dan kondisi variasi daya beban lampu pijar yang menggunakan dimmer. Hasil pengukuran conducted emission noise pada inverter modified 


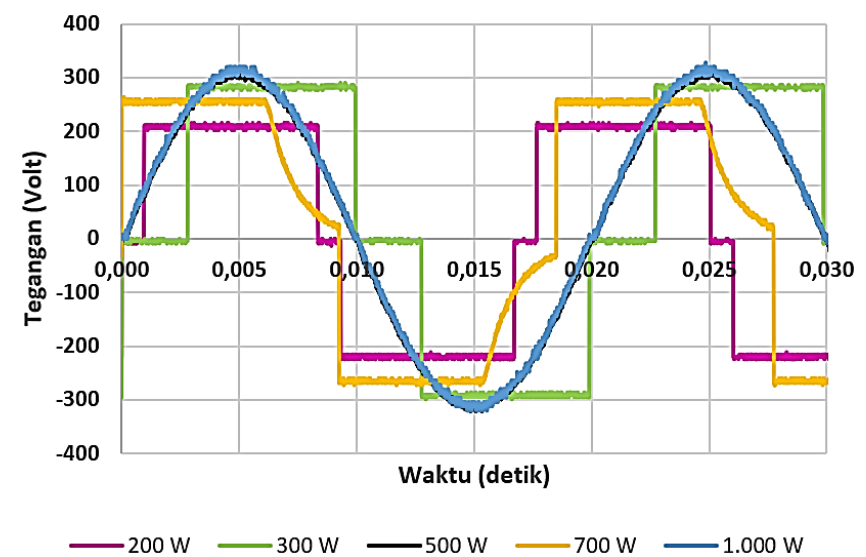

Gbr. 6 Hasil tegangan keluaran dari masing-masing inverter.

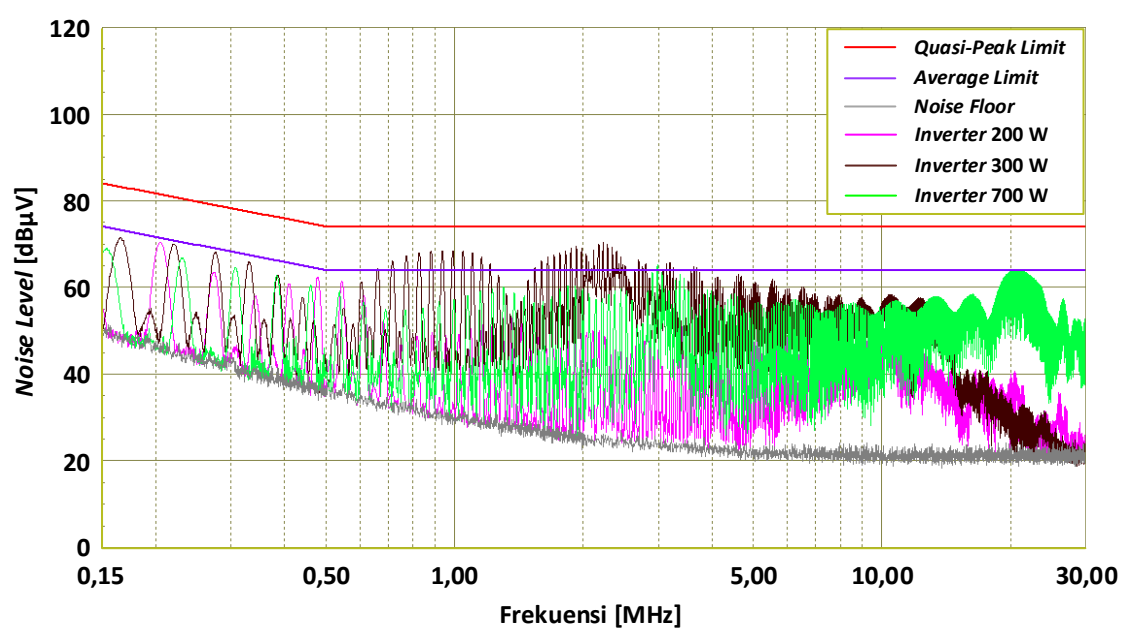

Gbr. 7 Hasil pengukuran conducted emission noise inverter model modified sine wave $200 \mathrm{~W}, 300 \mathrm{~W}$, dan $700 \mathrm{~W}$ (tanpa beban).

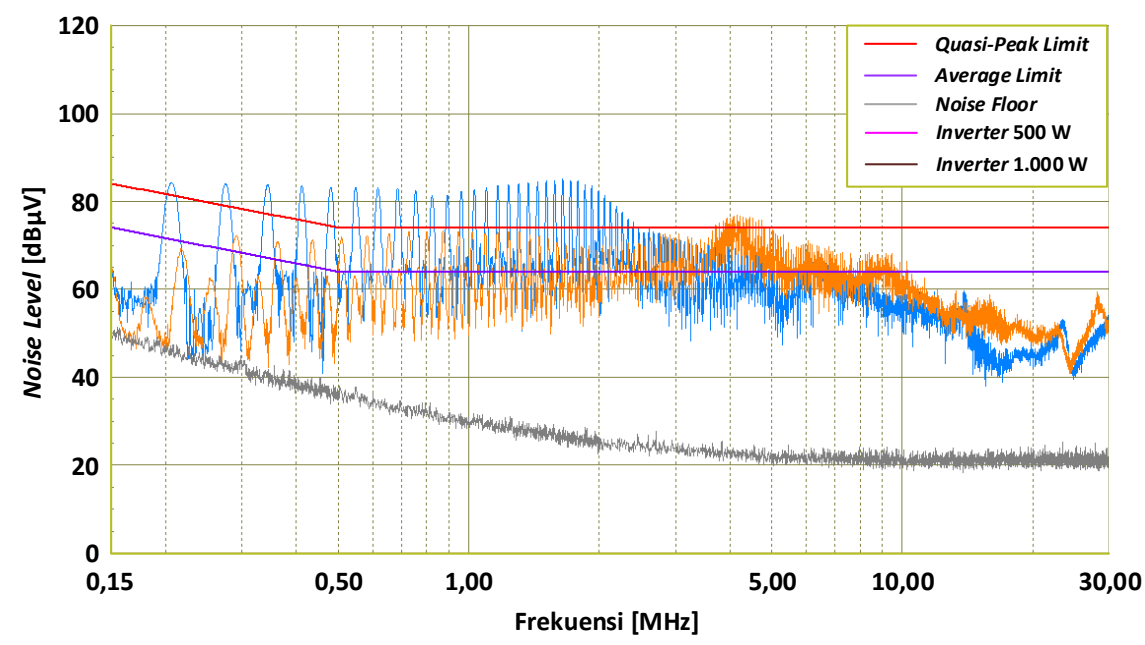

Gbr. 8 Hasil pengukuran conducted emission noise inverter model pure sine wave $500 \mathrm{~W}$ dan $1.000 \mathrm{~W}$ (tanpa beban).

dan pure sine wave pada kondisi tanpa beban ditunjukkan pada Gbr. 7 dan Gbr. 8.

Data pengukuran yang ditampilkan pada Gbr. 7 dan Gbr. 8 adalah noise floor serta noise dari inverter dan pada jalur DC yang dikumpulkan oleh DC-LISN dan kemudian diolah oleh spectrum analyzer menggunakan detektor peak. Noise floor diukur pada saat inverter belum dinyalakan. Nilai noise floor yang terukur sangat kecil $(20-50 \mathrm{~dB} \mu \mathrm{V}$ atau $0,01-0,316 \mathrm{mV})$ sehingga dapat dijadikan acuan terhadap nilai conducted emission noise yang dihasilkan oleh masing-masing inverter. Terukurnya nilai peak noise masing-masing inverter menandakan bahwa meskipun inverter belum diberi beban, noise di jalur DC sudah muncul dan memiliki risiko timbulnya gangguan elektromagnetik secara konduksi. 


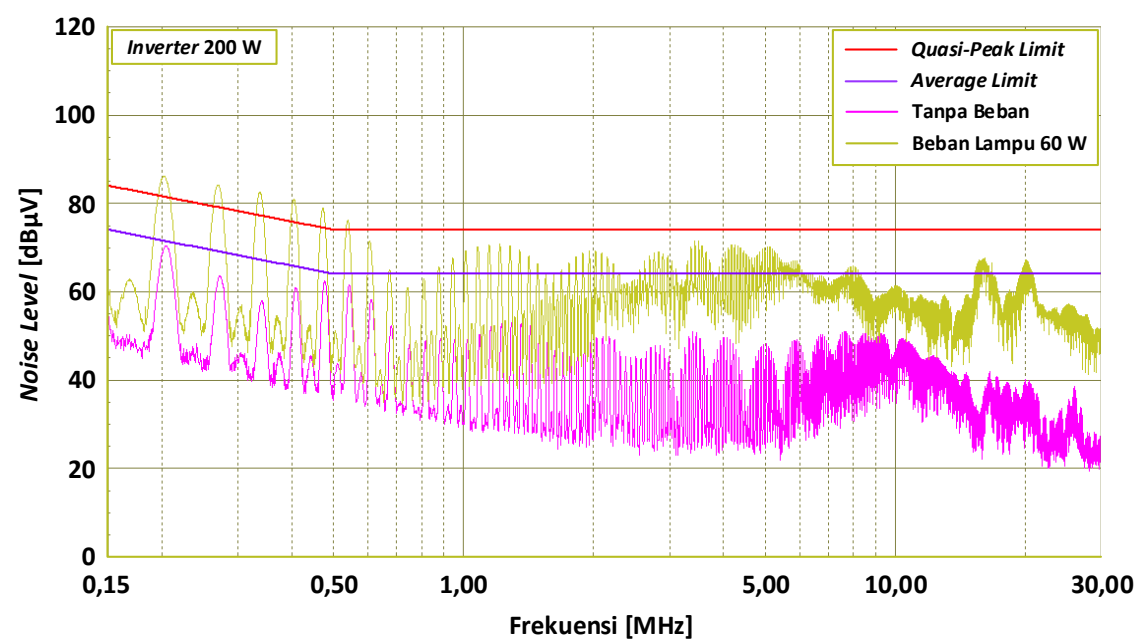

Gbr. 9 Hasil pengukuran conducted emission noise inverter $200 \mathrm{~W}$ tanpa beban dan terhubung dengan beban lampu pijar $60 \mathrm{~W}$.

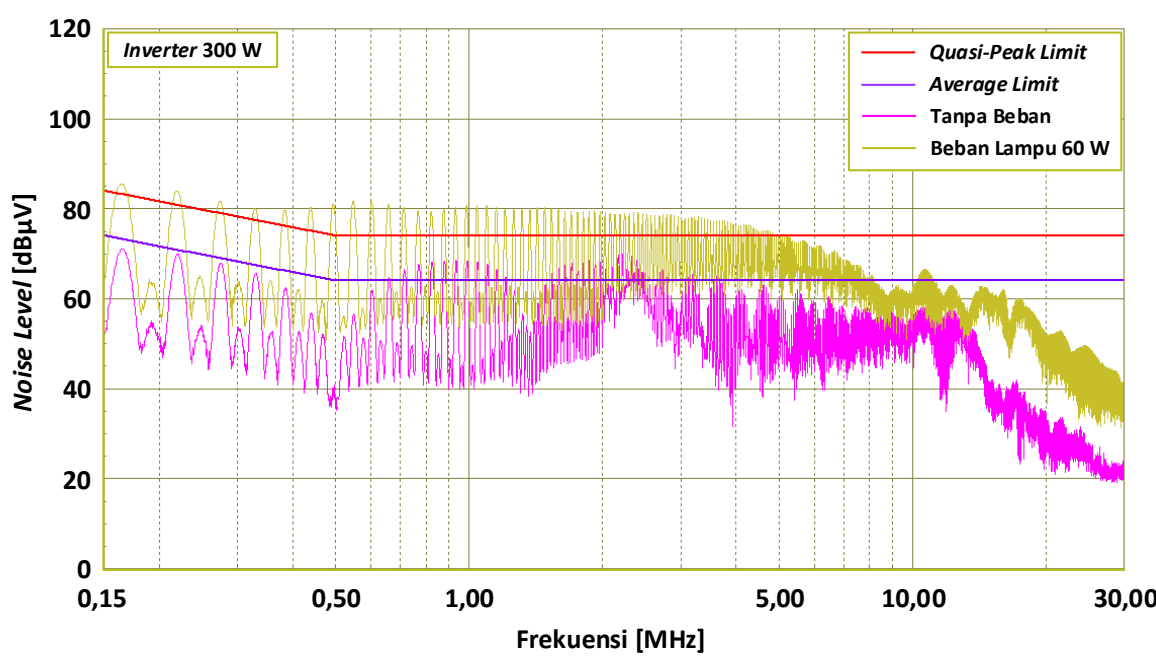

Gbr. 10 Hasil pengukuran conducted emission noise inverter $300 \mathrm{~W}$ tanpa beban dan terhubung dengan beban lampu pijar $60 \mathrm{~W}$.

Hasil pengukuran pada Gbr. 7 menunjukkan bahwa karakteristik peak noise yang ditimbulkan oleh masing-masing inverter cukup bervariasi pada rentang frekuensi $150 \mathrm{kHz}$ sampai $30 \mathrm{MHz}$. Namun, untuk frekuensi di atas $10 \mathrm{MHz}$, peak noise level dari inverter $700 \mathrm{~W}$ relatif lebih tinggi dibanding inverter lainnya, yakni lebih dari $60 \mathrm{~dB} \mu \mathrm{V}$. Hal ini menunjukkan bahwa inverter $700 \mathrm{~W}$ cukup intensif dalam menghasilkan gangguan konduksi pada rentang frekuensi 10 $\mathrm{MHz}$ sampai $30 \mathrm{MHz}$. Hal yang sama juga ditunjukkan oleh inverter $300 \mathrm{~W}$ pada rentang frekuensi yang lebih rendah, yakni sekitar $500 \mathrm{kHz}$ sampai $5 \mathrm{MHz}$, sedangkan untuk inverter 200 $\mathrm{W}$, peak noise yang dihasilkan tidak terlalu tinggi dibandingkan dengan inverter lainnya. Untuk inverter model pure sine wave pada Gbr. 8, hasil pengukuran peak noise pada inverter $500 \mathrm{~W}$ cukup tinggi dibandingkan dengan inverter $1.000 \mathrm{~W}$ pada rentang frekuensi $150 \mathrm{kHz}$ sampai $2 \mathrm{MHz}$.

Indikator quasi-peak dan average limit berdasarkan standar IEC 62690:2017 diberikan pada grafik di Gbr. 7 dan Gbr. 8 guna meninjau tinggi peak noise level yang terukur dari masing-masing inverter. Bila peak noise yang terukur masih berada di bawah level average-limit, maka gangguan yang ditimbulkan oleh inverter tersebut masih relatif aman terhadap lingkungan elektromagnetik di sekitarnya. Sementara itu, apabila hasil pengukuran peak noise berada di antara quasipeak dan average limit atau bahkan melebihi quasi-peak limit, maka gangguan yang dihasilkan oleh inverter tersebut berpotensi mengganggu lingkungan elektromagnetik di sekitarnya [19], [21]. Perangkat ukur seperti EMI Receiver yang memiliki detektor quasi-peak dan average diperlukan untuk mengevaluasi nilai-nilai peak noise tersebut lebih lanjut. Meskipun demikian, penggunaan spectrum analyzer pada tahap awal ini cukup dapat menggambarkan secara kualitatif tinggi atau tidaknya potensi gangguan yang dihasilkan inverter saat beroperasi.

Dari semua inverter yang diukur pada kondisi tanpa beban, inverter model pure sine wave kapasitas $500 \mathrm{~W}$ dan $1.000 \mathrm{~W}$ memiliki beberapa peak noise yang melebihi average dan quasi-peak limit. Selain itu, peak noise dari inverter model modified sine wave $300 \mathrm{~W}$ juga berada di atas average limit. Hal ini perlu menjadi perhatian karena dapat berpotensi memberikan gangguan ke lingkungan elektromagnetik lainnya pada frekuensi-frekuensi peak noise tersebut. 


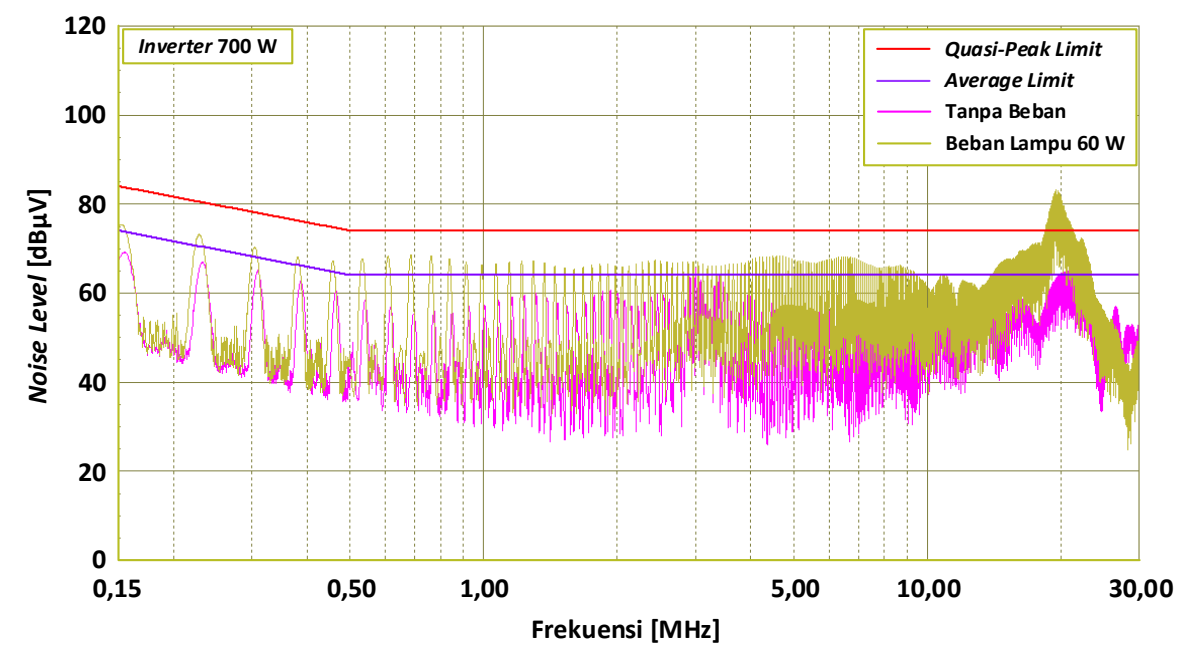

Gbr. 11 Hasil pengukuran conducted emission noise inverter $700 \mathrm{~W}$ tanpa beban dan terhubung dengan beban lampu pijar $60 \mathrm{~W}$.

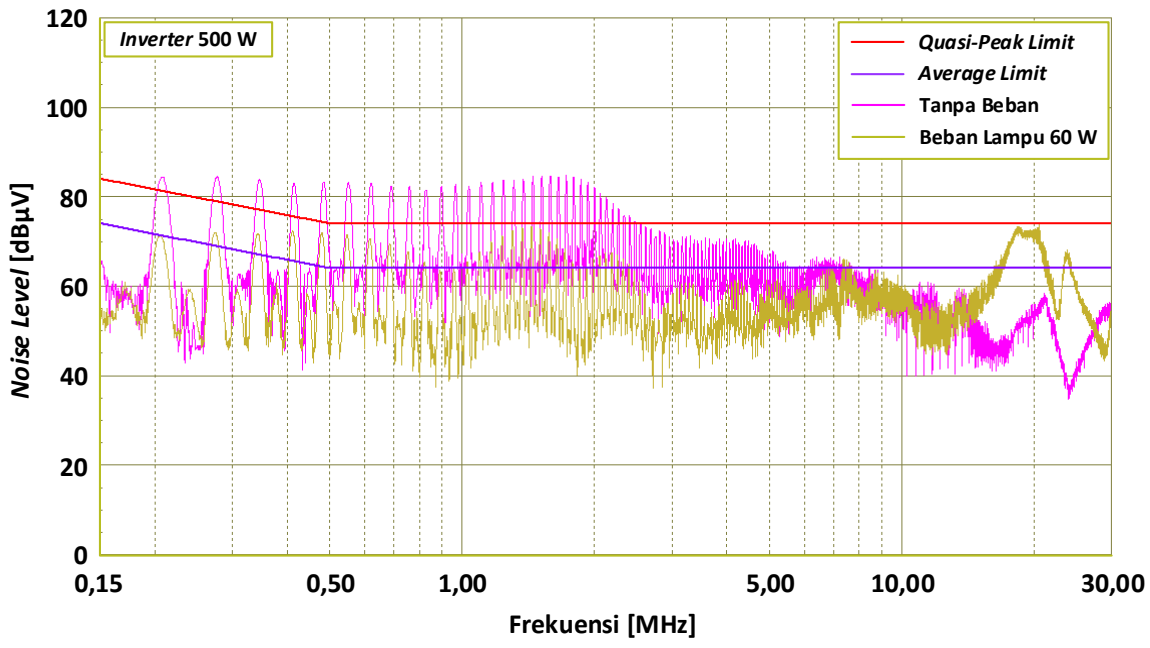

Gbr. 12 Hasil pengukuran conducted emission noise inverter $500 \mathrm{~W}$ tanpa beban dan terhubung dengan beban lampu pijar $60 \mathrm{~W}$.

Selanjutnya, hasil pengukuran conducted emission noise pada masing-masing inverter saat diberi beban lampu pijar 60 W ditampilkan pada Gbr. 9 sampai Gbr. 13. Pada pengukuran inverter model modified sine wave $200 \mathrm{~W}$ yang terhubung dengan beban lampu pijar $60 \mathrm{~W}$, peak noise yang terukur naik secara signifikan dibandingkan dengan kondisi tanpa beban (Gbr. 9). Hal ini menunjukkan adanya peningkatan aktivitas switching inverter pada sistem internal inverter saat melakukan konversi daya guna dapat menyesuaikan tegangan dan frekuensi keluaran yang dibutuhkan oleh beban lampu pijar. Hal yang sama terjadi pula pada inverter model modified sine wave $300 \mathrm{~W}$ dan $700 \mathrm{~W}$, seperti ditunjukkan pada Gbr. 10 dan Gbr. 11.

Hasil peak noise yang terukur pada inverter model modified sine wave ini pun bahkan cukup banyak berada pada level yang melebihi quasi-peak limit sehingga adanya beban lampu pijar $60 \mathrm{~W}$ yang terhubung dengan inverter di sisi AC menyebabkan kenaikan peak noise level yang sangat signifikan dan berpotensi mengganggu lingkungan elektromagnetik di sekitarnya.

Sementara itu, hal yang berbeda ditunjukkan oleh inverter model pure sine wave $500 \mathrm{~W}$ dan $1.000 \mathrm{~W}$. Pada Gbr. 12 dan
Gbr. 13, kedua inverter tersebut sama-sama menghasilkan peak noise level yang lebih rendah saat diberi beban lampu pijar 60 W bila dibandingkan dengan kondisi tanpa beban pada frekuensi rendah (di bawah $10 \mathrm{MHz}$ ). Namun, pada frekuensi yang lebih tinggi, di sekitar $15 \mathrm{MHz}$ sampai $20 \mathrm{MHz}$, terdapat kenaikan peak noise yang cukup signifikan. Jika ditinjau dari sisi internal inverter, proses filter noise yang ada pada inverter model sine wave pada saat ada beban yang terhubung cukup membantu menekan peak noise di frekuensi rendah.

Pada inverter model pure sine wave, masih didapati hasil pengukuran peak noise yang melebihi average limit untuk kondisi inverter terhubung dengan beban di frekuensi tinggi. Hal tersebut menandakan masih adanya potensi gangguan elektromagnetik di jalur DC pada frekuensi tinggi meskipun sebagian besar peak noise level turun pada daerah frekuensi yang lebih rendah.

Dengan demikian, adanya penambahan beban di sisi AC untuk seluruh model inverter dapat meningkatkan peak noise level pada inverter, terutama pada frekuensi tinggi. Hal ini terjadi karena adanya kebutuhan supply arus, penyesuaian tegangan, dan frekuensi keluaran ke beban yang mengakibatkan kinerja inverter menjadi lebih berat. Hal 


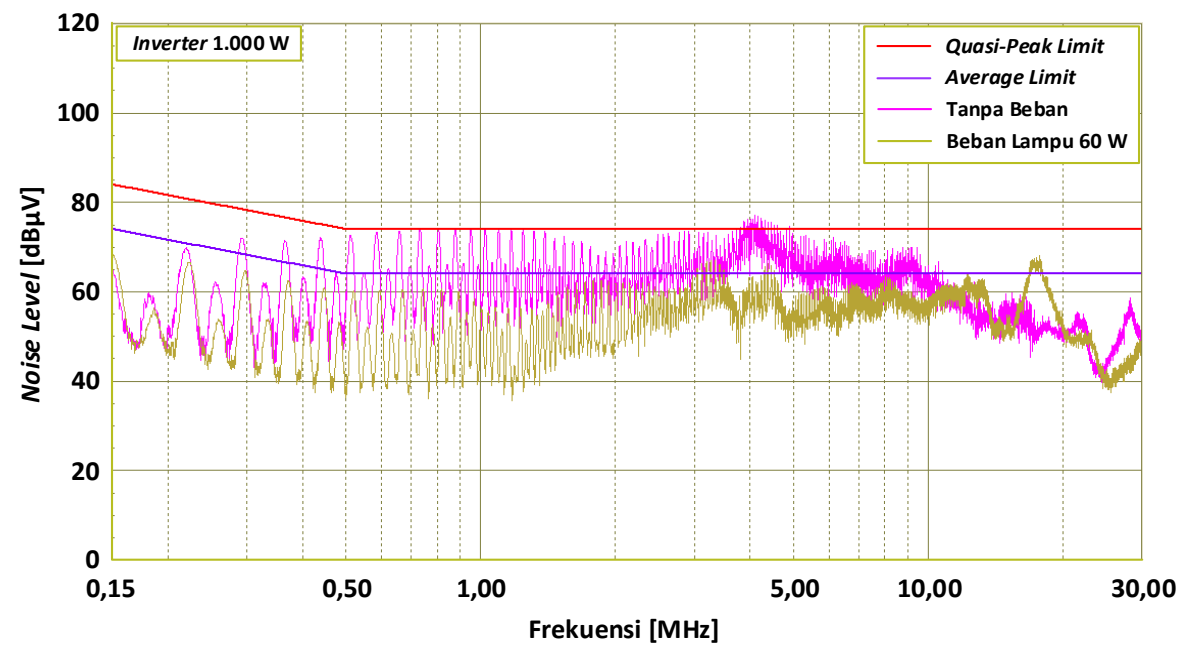

Gbr. 13 Hasil pengukuran conducted emission noise inverter $1.000 \mathrm{~W}$ tanpa beban dan terhubung dengan beban lampu pijar $60 \mathrm{~W}$.

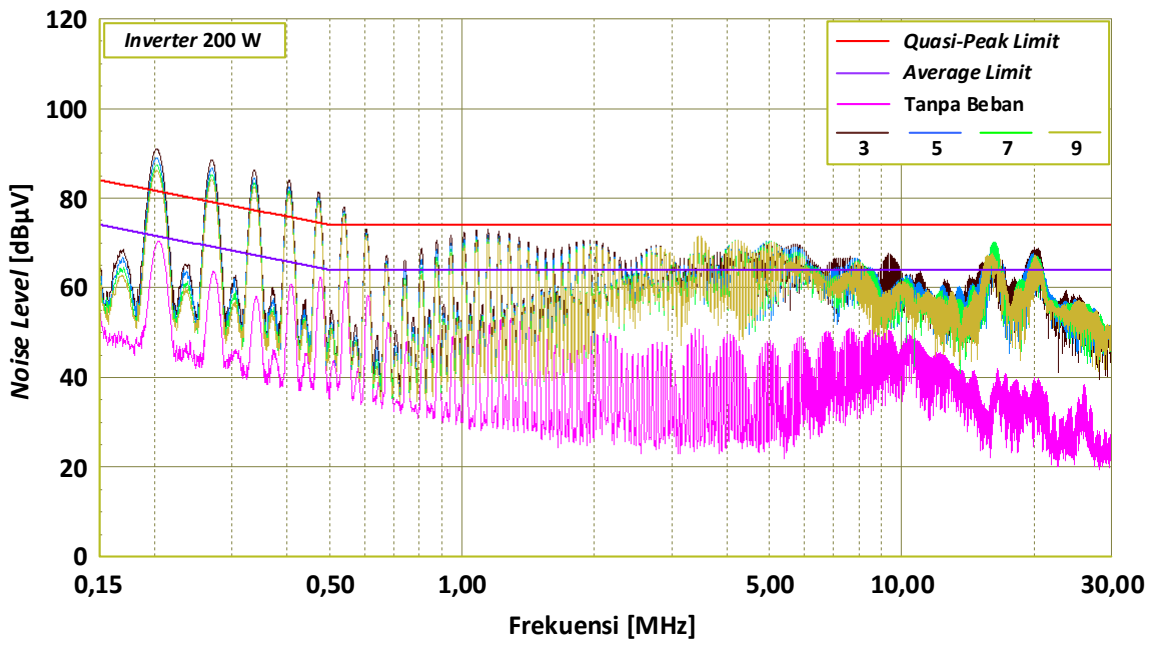

Gbr. 14 Hasil pengukuran conducted emission noise inverter $200 \mathrm{~W}$ tanpa beban dan terhubung dengan beban lampu pijar beserta dimmer.

TABEL I

Data Variasi Daya Lampu PiJar 60 W MengGunakan DIMMER

\begin{tabular}{|c|c|c|c|c|c|}
\hline \multirow{2}{*}{$\begin{array}{c}\text { No. } \\
\text { Dimmer }\end{array}$} & \multicolumn{5}{|c|}{ Daya Lampu Pijar (W) } \\
\cline { 2 - 6 } & $\begin{array}{c}\text { Inverter } \\
\mathbf{2 0 0} \mathbf{~ W}\end{array}$ & $\begin{array}{c}\text { Inverter } \\
\mathbf{3 0 0} \mathbf{~ W}\end{array}$ & $\begin{array}{c}\text { Inverter } \\
\mathbf{5 0 0} \mathbf{~ W}\end{array}$ & $\begin{array}{c}\text { Inverter } \\
\mathbf{7 0 0} \mathbf{~ W}\end{array}$ & $\begin{array}{c}\text { Inverter } \\
\mathbf{1 . 0 0 0} \mathbf{~ W}\end{array}$ \\
\hline 3 & 15,40 & 27,86 & 27,30 & 20,75 & 28,16 \\
\hline 5 & 27,23 & 38,27 & 41,82 & 34,05 & 42,91 \\
\hline 7 & 37,77 & 48,11 & 53,08 & 44,71 & 52,46 \\
\hline 9 & 44,90 & 54,32 & 58,38 & 51,52 & 58,84 \\
\hline
\end{tabular}

tersebut dapat diantisipasi dengan cara memberi filter pada masukan daya inverter agar noise tidak merambat ke jalur DC [25].

Untuk kondisi inverter yang terhubung dengan beban lampu pijar beserta dimmer, nilai daya lampu divariasikan menggunakan dimmer. Penomoran penyalaan dimmer divariasikan dari nomor 3, 5, 7, dan 9. Semakin besar nomor penyalaan, daya lampu akan semakin mendekati nilai nominal daya yang tertera pada lampu, yakni $60 \mathrm{~W}$. Nilai daya lampu yang bersesuaian dengan nomor penyalaan dimmer ditunjukkan pada Tabel I.
Dari tabel tersebut dapat dilihat bahwa inverter model modified sine wave $(200 \mathrm{~W}, 300 \mathrm{~W}$, dan $700 \mathrm{~W})$ menunjukkan nilai daya yang tidak terlalu mendekati $60 \mathrm{~W}$ meskipun dimmer sudah diatur pada posisi nomor 9, sedangkan pada inverter model pure sine wave $(500 \mathrm{~W}$ dan $1.000 \mathrm{~W})$, nilai daya lampu mendekati $60 \mathrm{~W}$ saat dimmer diatur pada posisi nomor 9. Hal tersebut terjadi karena bentuk gelombang tegangan inverter model modified sine wave tidak sinusoidal murni yang diakibatkan adanya harmonik arus dan tegangan yang tinggi sehingga nilai rugi-rugi daya meningkat. Sementara itu, tegangan keluaran dari inverter model pure sine wave berbentuk sinusoidal murni dengan nilai harmonik arus dan tegangan yang sangat rendah sehingga rugi-rugi daya yang timbul cukup kecil [26]. Hal ini bersesuaian dengan data arus dan tegangan Total Harmonic Distortion (THD) yang terukur pada masing-masing inverter, yang ditampilkan pada Tabel II dan Tabel III.

Hasil pengukuran conducted emission noise masing-masing inverter pada kondisi terhubung dengan beban lampu pijar beserta dimmer ditunjukkan pada Gbr. 14 sampai Gbr. 18. Pengukuran conducted emission noise inverter model modified 


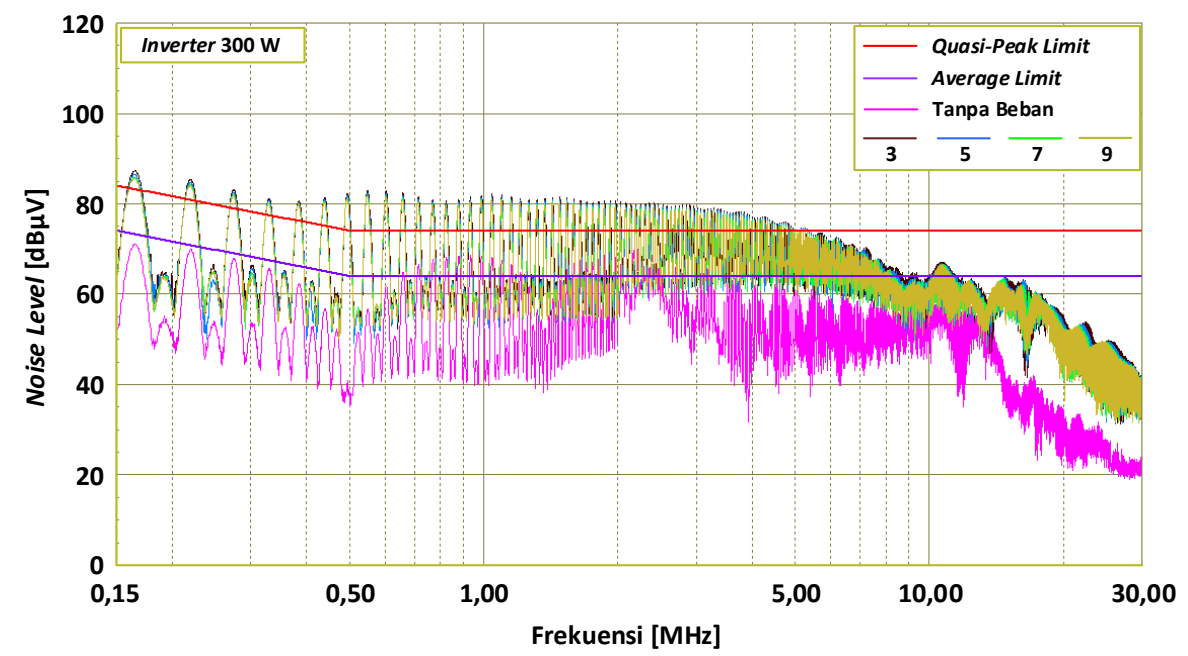

Gbr. 15 Hasil pengukuran conducted emission noise inverter $300 \mathrm{~W}$ tanpa beban dan terhubung dengan beban lampu pijar beserta dimmer.

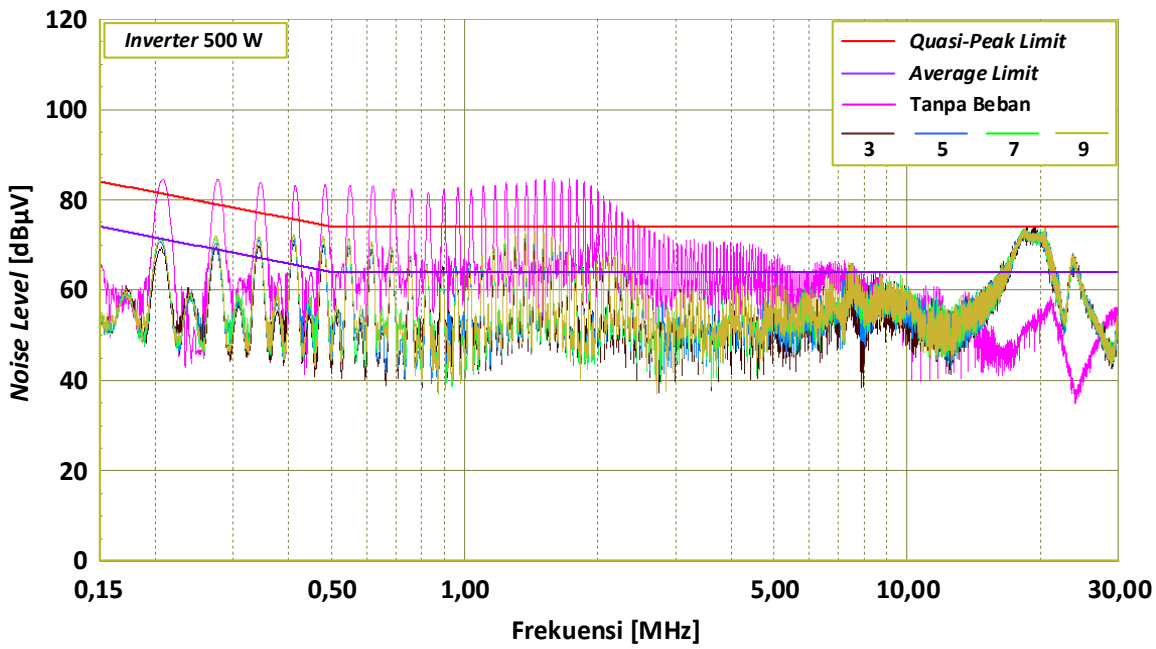

Gbr. 16 Hasil pengukuran conducted emission noise inverter $500 \mathrm{~W}$ tanpa beban dan terhubung dengan beban lampu pijar beserta dimmer.

TABEL II

DATA ARUS THD SETIAP INVERTER

\begin{tabular}{|c|c|c|c|c|c|}
\hline \multirow{2}{*}{$\begin{array}{c}\text { No. } \\
\text { Dimmer }\end{array}$} & $\begin{array}{c}\text { Arus THD (\%) } \\
\mathbf{2 0 0} \mathbf{~ W}\end{array}$ & $\begin{array}{c}\text { Inverter } \\
\mathbf{3 0 0} \mathbf{~ W}\end{array}$ & $\begin{array}{c}\text { Inverter } \\
\mathbf{5 0 0} \mathbf{W}\end{array}$ & $\begin{array}{c}\text { Inverter } \\
\mathbf{7 0 0} \mathbf{W}\end{array}$ & $\begin{array}{c}\text { Inverter } \\
\mathbf{1 . 0 0 0} \mathbf{~ W}\end{array}$ \\
\hline 3 & 127,65 & 81,93 & 77,03 & 116,55 & 76,58 \\
\hline 5 & 58,84 & 48,40 & 51,02 & 56,74 & 50,04 \\
\hline 7 & 30,57 & 29,80 & 28,64 & 30,93 & 30,44 \\
\hline 9 & 34,55 & 29,53 & 4,28 & 29,52 & 4,17 \\
\hline
\end{tabular}

sine wave $(200 \mathrm{~W}, 300 \mathrm{~W}$, dan $700 \mathrm{~W})$ menunjukkan nilai peak noise yang terukur cukup fluktuatif di frekuensi tinggi. Peak noise level yang cukup tinggi terukur saat daya dari lampu pijar bernilai rendah. Hal ini disebabkan perlunya inverter melakukan penyesuaian berupa kompensasi daya terhadap beban sehingga kinerja inverter model ini menjadi cukup berat [21]. Meskipun demikian, seluruh hasil pengukuran inverter model modified sine wave saat terhubung dengan beban lampu pijar beserta dimmer memiliki pola peak noise yang cukup mendekati satu sama lain.
TABEL III

DATA TEGANGAN THD SETIAP INVERTER

\begin{tabular}{|c|c|c|c|c|c|}
\hline \multirow{2}{*}{$\begin{array}{c}\text { No. } \\
\text { Dimmer }\end{array}$} & \multicolumn{5}{|c|}{ Tegangan THD (\%) } \\
\cline { 2 - 6 } & $\begin{array}{c}\text { Inverter } \\
\mathbf{2 0 0} \mathbf{~ W}\end{array}$ & $\begin{array}{c}\text { Inverter } \\
\mathbf{3 0 0} \mathbf{~ W}\end{array}$ & $\begin{array}{c}\text { Inverter } \\
\mathbf{5 0 0} \mathbf{~ W}\end{array}$ & $\begin{array}{c}\text { Inverter } \\
\mathbf{7 0 0} \mathbf{W}\end{array}$ & $\begin{array}{c}\text { Inverter } \\
\mathbf{1 . 0 0 0} \mathbf{W}\end{array}$ \\
\hline 3 & 32,15 & 26,91 & 1,33 & 26,58 & 1,29 \\
\hline 5 & 34,47 & 30,34 & 1,38 & 27,95 & 1,24 \\
\hline 7 & 37,14 & 31,77 & 1,24 & 30,04 & 1,16 \\
\hline 9 & 36,08 & 30,37 & 1,06 & 30,45 & 1,01 \\
\hline
\end{tabular}

Hasil yang berbeda ditunjukkan pada pengukuran inverter model pure sine wave, yakni $500 \mathrm{~W}$ dan $1.000 \mathrm{~W}$. Dari segi fluktuasi noise di frekuensi tinggi, semakin tinggi daya lampu pijar, noise yang terukur menjadi lebih tinggi. Hal ini disebabkan oleh lebih tingginya nilai arus yang dibutuhkan untuk memasok daya yang lebih besar pada beban, sehingga proses switching inverter menjadi lebih cepat dan berpotensi menaikkan peak noise level di jalur DC [16], [21].

Dari keseluruhan hasil pengukuran pada kondisi inverter terhubung dengan beban lampu pijar beserta dimmer, inverter 


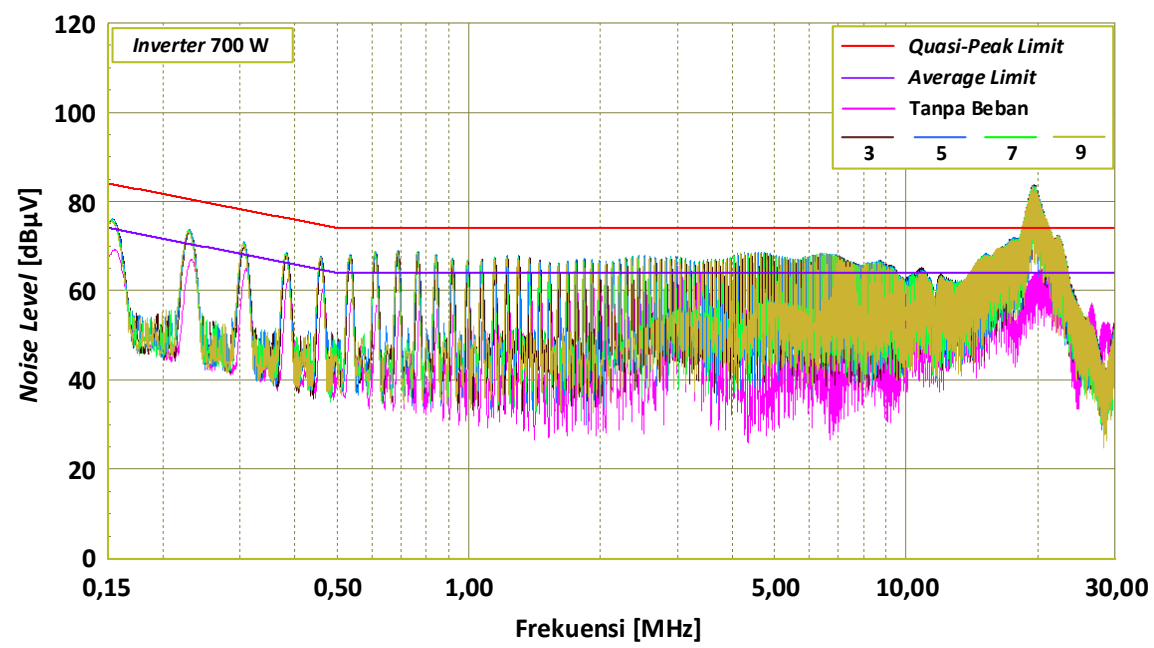

Gbr. 17 Hasil pengukuran conducted emission noise inverter $700 \mathrm{~W}$ tanpa beban dan terhubung dengan beban lampu pijar beserta dimmer.

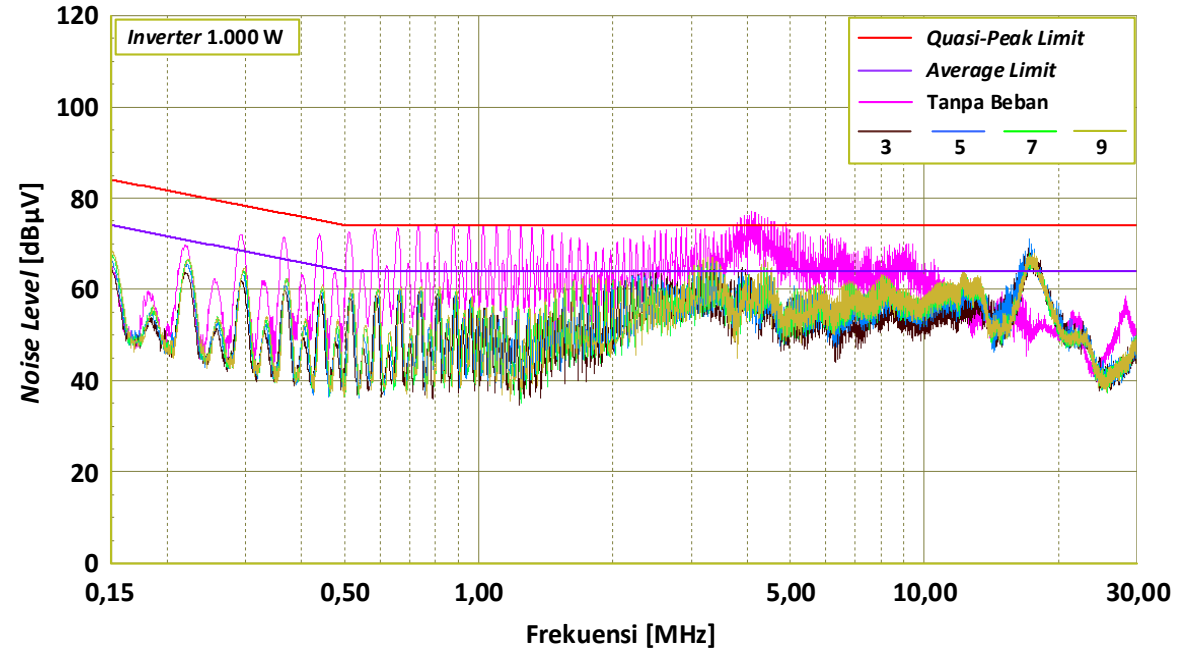

Gbr. 18 Hasil pengukuran conducted emission noise inverter $1.000 \mathrm{~W}$ tanpa beban dan terhubung dengan beban lampu pijar beserta dimmer.

model pure sine wave $500 \mathrm{~W}$ dan $1.000 \mathrm{~W}$ memiliki peak noise level yang cukup rendah dan paling aman untuk digunakan. Hal tersebut didukung pula oleh nilai arus dan tegangan THD yang rendah sehingga inverter dapat beroperasi secara optimal dalam memasok daya pada beban AC tanpa menghasilkan efek samping berupa conducted emission noise yang tinggi di jalur DC.

\section{KESIMPULAN}

Karakterisasi conducted emission noise pada inverter sistem PV off-grid dapat dilakukan dengan menerapkan metode pengukuran berdasarkan standar IEC 62920:2017 dan CISPR 25:2016, baik untuk kondisi standalone maupun terhubung dengan beban. Hasil karakterisasi conducted emission noise pada inverter model modified sine wave tanpa beban menunjukkan peak noise yang terukur bernilai cukup tinggi pada inverter $300 \mathrm{~W}$ dan $700 \mathrm{~W}$, tetapi masih berada di bawah quasi-peak limit. Sementara itu, inverter model pure sine wave $500 \mathrm{~W}$ memiliki peak noise yang lebih tinggi dibandingkan dengan inverter $1.000 \mathrm{~W}$ pada frekuensi rendah, sehingga lebih berpotensi memberikan gangguan pada jalur DC. Adanya penambahan beban lampu pijar $60 \mathrm{~W}$ di sisi AC untuk seluruh model inverter dapat meningkatkan peak noise level pada inverter, terutama pada frekuensi tinggi. Dari keseluruhan hasil pengukuran pada kondisi inverter terhubung dengan beban lampu pijar beserta dimmer, inverter model pure sine wave 500 $\mathrm{W}$ dan $1.000 \mathrm{~W}$ memiliki peak noise level yang cukup rendah dan berpotensi lebih sedikit untuk menimbulkan gangguan elektromagnetik di sisi DC. Meskipun masih perlu dilakukan deteksi quasi-peak dan average di beberapa frekuensi kritis untuk mendapatkan hasil yang lebih kuantitatif, pengukuran yang telah dilakukan cukup dapat menggambarkan karakteristik conducted emission noise yang dihasilkan oleh berbagai jenis inverter yang umumnya digunakan pada sistem PV off-grid.

\section{UCAPAN TERIMA KASIH}

Ucapan terima kasih ditujukan kepada Tim Laboratorium Electromagnetic Compatibility (EMC) Pusat Penelitian Teknologi Pengujian - LIPI, Sekolah Teknik Elektro dan Informatika - ITB, dan ANRGI (Accessible, Natural, Renewable, Growing, Interactive/Implementation) Project 
antara ITB dan P2TP - LIPI atas dana, fasilitas, dan dukungannya dalam melakukan kegiatan penelitian ini.

\section{REFERENSI}

[1] "Peraturan Menteri Energi dan Sumber Daya Mineral Republik Indonesia No. 12 Tahun 2017 tentang Pemanfaatan Sumber Energi Terbarukan untuk Penyediaan Tenaga Listrik," Kementrian ESDM, Jakarta, Indonesia, hal. 1-22, 2017.

[2] K. Basaran, N.S. Cetin, dan S. Borekci, "Energy Management for OnGrid and Off-Grid Wind/PV and Battery Hybrid Systems," IET Renew. Power Gener., Vol. 11, No. 5, hal. 642-649.

[3] J. Huang dan K. Li, "Suppressing EMI Peaks Through Auto-Screening Carrier Phase-Shift Scheme in a PV System Composed of Parallel SinglePhase Inverters," IEEE Trans. Electromagn. Compat., Vol. 61, No. 1, hal. 82-89, 2019.

[4] O. Yade, C. Martin, C. Vollaire, A. Bréard, M. Ali, R. Meuret, H. Morel, "Improved Layout of Inverter for EMC Analysis," More Electr. Aircr., No. 1, hal. 3-6, 2018, [Online]. https://hal.archives-ouvertes.fr/hal01715021 tanggal akses: 10-Des-2020.

[5] Y.H. Dong, M.Y. Liu, dan L. Cao, "EMI Noise Testing and Diagnosis for PV Inverter," Advanced Materials Research, Vol. 805-806, hal. 31-35, 2013.

[6] N. Henze, G. Bopp, T. Degner, H. Häberlin, dan S. Schattner, "Radio Interference on the DC Side of PV Systems," 17th European Photovoltaic Solar Energy Conference and Exhibition, 2001, hal. 22-25.

[7] N. Harpawi, M.Y. Hariyawan, dan N. Posma, "Teknik Mitigasi Conducted Emission pada LED Driver Topologi Buck dengan Metode Random Up Spreading Switching Frequency," J. Elem., Vol. 5, No. 2, hal. 50-58, 2019.

[8] Y. Lu, Z. Chen, dan H. Huang, "The System for the Reduction of Conducted Electromagnetic Interference Emission from Switching Power Supply," Third International Conference on Intelligent Information Hiding and Multimedia Signal Processing (IIH-MSP 2007), 2007, hal. 397-402.

[9] N. Boonpirom, "Conducted and Radiated Noise Reduction Using Circuit Balance on Double Switch Converter," 2010 Conference Proceedings IPEC, 2010, hal. 317-322.

[10] S. Wang dan F.C. Lee, "Analysis and Applications of Parasitic Capacitance Cancellation Techniques for EMI Suppression," IEEE Trans. Ind. Electron., Vol. 57, No. 9, hal. 3109-3117, Sep. 2010.

[11] D. Hamza dan P. Jain, "Conducted Electromagnetic Emissions Analysis in Grid-tied PV System," IEICE, 2009, hal. 2-5.

[12] K.R. Li, K.Y. See, dan R.M.S. Bandara, "Impact Analysis of Conducted Emission Measurement Without LISN," IEEE Trans. Electromagn. Compat., Vol. 58, No. 3, hal. 776-783, 2016.

[13] Y. Wang, S. Bai, X. Guo, S. Jin, Y. Zhang, J. Eriksson, L. Qu, J. Huang, dan J. Fan, "Conducted-emission Modeling for a Switched-Mode Power Supply (SMPS)," 2015 IEEE Symposium on Electromagnetic Compatibility and Signal Integrity, EMCSI 2015, 2015, hal. 314-319.
[14] W. Ananda, S.A. Cahyadi, I. Inayaturohman, dan D. Hamdani, "The Effect of the Grounding Condition of Line Impedance Stabilization Network on the Measurement Validity of Conducted Emission Parameter," Proc. Int. Conf. on High Voltage Engineering and Power Systems, ICHVEPS 2017, 2017, hal. 498-502.

[15] M. Naim, "Rancangan Sistem Kelistrikan PLTS Off Grid 1000 watt di Desa Mahalona Kecamatan Towuti," J. Ilm. Tek. Mesin, Vol. 9, No. 1, hal. 27-32, 2017.

[16] S. Saodah dan S. Utami, "Perancangan Sistem Grid Tie Inverter pada Pembangkit Listrik Tenaga Surya," ELKOMIKA J. Tek. Energi Elektr. Tek. Telekomun. Tek. Elektron., Vol. 7, No. 2, hal. 339-350, 2019.

[17] "Vehicles, Boats and Internal Combustion Engines - Radio Disturbance Characteristics - Limits and Methods of Measurement for the Protection of On-board Receivers," CISPR 25:2016, 2016.

[18] "Photovoltaic Power Generating Systems - EMC Requirements and Test Methods for Power Conversion Equipment," IEC 62920:2017, 2017

[19] "Specification for Radio Disturbance and Immunity Measuring Apparatus and Methods - Part 1-1: Radio Disturbance and Immunity Measuring Apparatus - Measuring Apparatus," CISPR 16-1-1:2019, 2019.

[20] S. Okuyama, K. Osabe, K.T. And, dan H. Muramatsu, "Investigation on Effectiveness of Very High Frequency Line Impedance Stabilization Network (VHF-LISN) for Measurement Reproducibility," 2013 International Symposium on Electromagnetic Compatibility, 2013, hal. 174-179.

[21] Yudhistira, "Identifikasi Gangguan Elektromagnetik pada Sisi DC Inverter Photovoltaic Off-Grid Menggunakan DC Line Impedance Stabilization Network," Tesis Program Magister, Institut Teknologi Bandung, Bandung, Indonesia, 2020.

[22] Yudhistira, D. Hamdani, dan S.P.B. Anggoro, "Characterization of DC Artificial Network Using Analytical Method for Conducted Emission Measurement of Photovoltaic Inverter," Proc. of the 12th Int. Conf. on Information Technology and Electrical Engineering (ICITEE 2020), 2020, hal. 192-197.

[23] H. Harmini dan T. Nurhayati, "Desain Sistem Rooftop Off Grid Panel Solar Photovoltaic," J. Pengemb. Rekayasa dan Teknol., Vol. 13, No. 2 , hal. 47-51, 2018.

[24] B. Hartono, S. Prayogo, dan B. Wahyu, "Pengembangan Kontrol Peningkatan Daya Listrik Rumah Tangga Menggunakan On/Off Grid Tie Inverter," J. Teknol. Elektro, Univ. Mercu Buana, Vol. 8, No. 3, hal. 192199, 2017.

[25] J. Jiraprasertwong dan C. Jettanasen, "Electromagnetic Interference in Photovoltaic System and Mitigation of Conducted Noise at DC Side," Proc. IEEE Region 10 Annual International Conference (TENCON), 2017, hal. 915-920.

[26] B.C. Neagu, G. Grigoras, dan F. Scarlatache, "The Influence of Harmonics on Power Losses in Urban Distribution Networks," 2016 Int. Symp. on Fundamentals of Electrical Engineering (ISFEE 2016), 2016 , hal. $2-5$. 